\title{
MANAGEMENT OF INTERGENERATIONAL ENVIRONMENTAL LIABILITIES: EXAMPLE OF DECOMMISSIONING OF NUCLEAR RESEARCH AND DEVELOPMENT FACILITIES
}

\author{
R. SJÖBLOM ${ }^{1} \&$ S. LINDSKOG ${ }^{2}$ \\ ${ }^{1}$ Waste Science and Technology, Luleå University of Technology, Sweden. \\ ${ }^{2}$ The Swedish Radiation Safety Authority, Sweden.
}

\begin{abstract}
The character is described of various prerequisites for and obstacles against fulfilment of the polluter pays principle in the case of decommissioning of old nuclear research and development (R\&D) facilities, and the relevance to other areas is analyzed. Background is compiled in the areas of Swedish old nuclear R\&D facilities, environmental liabilities in some areas, and legislation. Two completed decommissioning projects and two under planning are described together with some findings on planning for decommissioning and on cost estimation. Also, an example is given on developing a basis for regulation relating to small facilities. It is concluded that although the polluter pays principle is easy to understand, it may be complicated to implement, especially in cases where there is a gap in time between the operations and the decommissioning. Pitfalls may be plentiful and extensive awareness and substantial efforts are warranted for adequate funds to be available at the time when they are needed. Thus, it is essential that internationally available advice and knowledge be utilized, information exchanged, and necessary knowledge acquired. It is also important to realize that the planning is usually dictated by the needs for financial planning, and that there is a substantial difference between end of license and end of liability. A need for information exchange between different areas of technology is identified and it is hoped that the present work might contribute to such processes.

Keywords: cost calculation, liability, nuclear, polluter pays principle, segregated fund.
\end{abstract}

\section{INTRODUCTION}

It is part of human nature to strive for leaving a better world for the descendents. Consequently, the United Nations and others have put forward policies and strategies for sustainable development, and the following quote is taken from the Brundtland report [1]: 'Sustainable development is development that meets the needs of the present without compromising the ability of future generations to meet their own needs'.

In Sweden, sustainable development is included in our constitution [2], which states that 'the public institutions shall promote sustainable development leading to a good environment for present and future generations'.

The principle of sustainable development is closely related to the polluter pays principle which is expressed as follows in the Swedish Environmental Code [3]: 'Persons who pursue or have pursued an activity or taken a measure that causes damage or detriment to the environment shall be responsible, until such time as the damage or detriment ceases, for remedying it to the extent deemed reasonable'. Note that there is no limit for the responsibility, neither in time nor in magnitude. A corollary to the polluter pays principle is thus the principle of equity between generations, that is, that undue burdens should not be passed onto subsequent generations.

It is, however, permitted under the law to carry out activities that have a potential for causing damage. It is also permitted to carry out activities that lead to contamination, and that such contamination may persist for a long time. The requirement is that any such contamination or potential for damage be removed in a timely manner at the expense of the owner/operator.

The responsibility for protection of health and the environment thus rests solely with the operator/ owner. However, experience tells us that there may be shortcomings in this regard in some cases. 
There is also a strong common interest between an owner/operator and the public that the endpoint is satisfactory to all. Thus, legislation has been passed and Authorities have been established to instigate such work and also to supervise it so that it is carried out according to the best or at least good practice and that it is finished in a timely manner. It is also essential that interested parties and the public have full access to information.

These basic principles may seem easy and clear, but it has been (and still is) a rather long journey toward the full apprehension of their implications. Our studies of historical records, for example [4], from 1964, have shown that decommissioning and waste management were not very predominant issues in the early years of nuclear technology development. Eventually, it became evident, for example, that costs for decommissioning of a nuclear facility may well exceed those of the initial investment, thus turning issues such as investment and associated depreciation upside down.

The high costs of decommissioning of nuclear facilities are almost exclusively related to the contamination with man-made radionuclides and the associated difficulties in radiological surveying and radiation protection.

There are many obstacles of different character against compliance with the abovementioned polluter pays principle, especially in cases where there is a considerable gap in time between the period of operation and that of decommissioning. As will be described more fully later, The Swedish Radiation Safety Authority (SSM) is the Authority in Sweden that has the main task of overseeing the functioning of the application of the polluter pays principle in the nuclear field. This duty is not only to instigate responsible action from the operators/owners and to oversee it but also to carry out the research work required to achieve a pertinent knowledge base and to inform and communicate with interested parties and the public. Examples of related research work of this kind financed by SSM can be found in References [5-18].

\section{OBJECTIVES AND SCOPE}

The main objectives of this paper can be stated as

- To describe and analyze the character of various prerequisites for and obstacles against fulfillment of the polluter pays principle in the case of decommissioning of old nuclear research and development (R\&D) facilities.

- To analyze to what extent these findings can be generalized to apply also to other cases and other industrial areas.

First, background is compiled in three areas: the Swedish old nuclear R\&D facilities, environmental liabilities in some areas, and legislation. Then two completed decommissioning projects and two under planning are described together with some findings on planning for decommissioning and on cost estimation. Finally, an example is given on developing a basis for regulation relating to small facilities.

\section{BACKGROUND}

\subsection{Swedish nuclear R\&D facilities}

Sweden was one of the six countries that took part in the rush to build the first nuclear power stations. The other countries were United States, United Kingdom, France, Soviet Union, and Canada. All other countries with nuclear power reactors have had to turn to either of these for assistance [19]. 


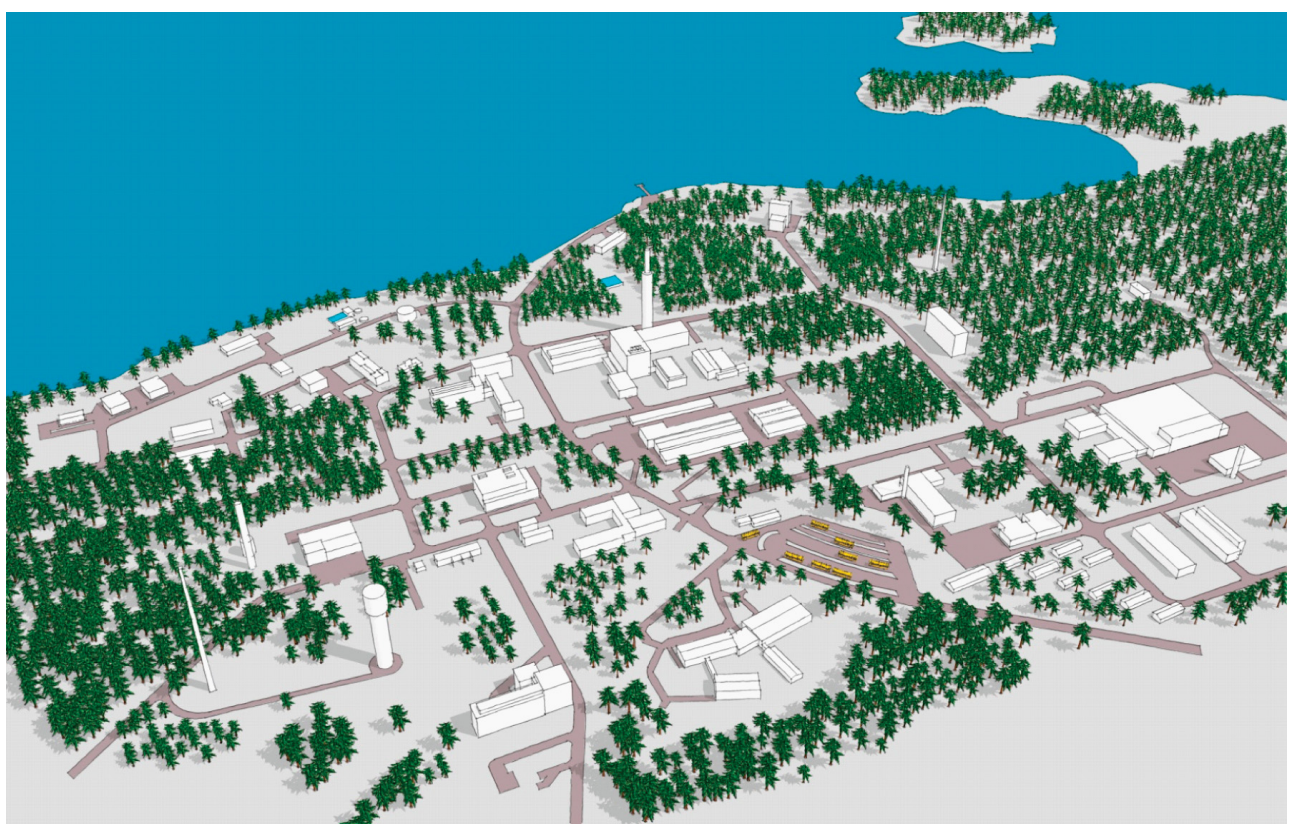

Figure 1: Artist's impression of the Studsvik site at around the year 1965. The illustration is based on contemporary drawings $[4,20]$ and aerial photographs [20-23]. (The site looks substantially different today.) The size of the site is approximately 1.0 by $0.7 \mathrm{~km}^{2}$. The Active Central Laboratory appears in the middle far right. Cf. text.

The first Swedish nuclear research reactor, R1, was located at the Royal Institute of Technology in Stockholm and was commissioned in 1954 [24]. The R1 reactor is dealt with further in Section 4.1.

Our first nuclear power plant was the Ågesta heavy water reactor [25] (65 MW, 10 MW for electricity generation and $55 \mathrm{MW}$ for district heating) in the southern part of Stockholm. It was commissioned in 1963 and was shut down in 1973.

These and most of the subsequent Swedish reactors came about as a result of a comprehensive research and development $(R \& D)$ program. Most of the work was conducted in the facilities at what one might have called our national nuclear laboratory, Studsvik, see Fig. 1 [20-23], located at the coast of the Baltic Sea about $80 \mathrm{~km}$ south of Stockholm. The contributions to this program from the Government alone (during the years 1955-1975) amounted to a total of around $1.7 \times 10^{9} €$ in today's currency [26]. This might be compared with the estimated cost for decommissioning of most of the old facilities, which amounts to about $0.22 \times 10^{9} €$.

The development program comprised the full nuclear fuel cycle, including heavy water moderation, reprocessing and mixed oxide (uranium + plutonium) fuel preparation. Reprocessing on a pilot scale was carried out at the Institute for Atomic Energy (IFA), now Institute for Energy Technology (IFE), at Kjeller, in the outskirts of Oslo in Norway. Also, a facility, called the Active Central Laboratory (ACL), was built at Studsvik for mixed oxide fuel fabrication on a pilot scale, but equipment for this was never installed. The facility did, however, host a full laboratory scale reprocessing facility. The exterior of the facility is shown in Fig. 1, and the decommissioning of the facility is dealt with in Section 4.2. 


\subsection{Environmental liabilities in some areas}

\subsubsection{Forestry}

Legislation on preservation and protection of forest extends beyond written records, and statements to this end exist even in our oldest written law, the older Westgothia law [27], from around the year 1220.

Early environmental legislation includes the statement by our Queen Kristina on March 18, 1639, when she banned burn-beating by the penalty of banishment. The wood from the forest had better use in our metals beneficiation industry.

The Swedish Forestry Act [28] was first issued in 1903, at around which time our forests were being converted from primeval (old-growth) forests to forests that are actively managed (including recurrent replanting). The law states that the owner must replant after harvest. When harvested forest land is sold, the seller may have to guarantee that the buyer will replant by means of securities.

\subsubsection{Mining, beneficiation and contaminated soil}

Our first record of a mining stock company relates to the Falun copper mine and is from the year 1288 [29,30]. The roasting of this sulfide ore gave rise to enormous emissions of sulfur dioxide, as has been witnessed by many travelers including Carl von Linné (who developed a system for categorization of plants). The smoke was bothering the miners and was disastrous to the crops around, but had the advantage that plague never reached the area. At least during most of the 17th and 18th centuries, there was a constant legal battle between the miners and the farmers on the emissions, and for long periods of time ore could be roasted only outside the growing season.

There are many old mine tailings and associated contaminated soil in Sweden that need remediation. Contaminated soil has also come about as a result of many other activities. At present, annual public spending in Sweden on remediation of old mine tailings and contaminated soil exceeds $\mathrm{M} €$ 55. According to the website of our Environmental Protection Agency (in Swedish: Naturvårdsverket), this is insufficient even to remediate those sites associated with the highest risks before the year 2050 .

For present day industrial activities, the legal entities associated with mining and beneficiation activities are fully responsible for any remediation required. Copper ore is no longer mined at the Falun site, but is mined at Boliden and Aitik. According to the Annual Report for the year 2008 of Boliden $\mathrm{AB}$, the Competent Authority has received guarantees for around $\mathrm{M} € 55$ to cover the environmental liabilities for the restoration associated with the Aitik mine alone.

Especially residues from mining of sulfide ores have the potential of causing increased releases over time as a result of the acidification that takes place if and when the residues come in contact with the oxygen in the air.

The heap of shale ash at Kvarntorp near Örebro constitutes an example of such a situation. It is a hundred meters high and comprises several tens of millions tons of material. The ash was generated during 1940-1965, when oil was extracted from the shale. Much of the carbon and sulfur in the shale was left uncombusted in the processes. The residues are burning still today, and for this reason, the heap is kept dry and the releases are low. If no remedial action is taken, the heap will cool sooner or later, and it can then be feared that acidification takes place and the releases become substantially increased.

At the same time, it should be realized that there is a substantial difference between on one hand the cautious modeling made to ensure that environmental impact is acceptable and, on the other hand, realistic modeling. The streams and lakes surrounding the abovementioned Falun copper mine have a surprisingly healthy biological life [29]. 


\subsubsection{Offshore}

There are no offshore rigs for oil production in the Swedish waters and consequently no associated domestic need for decommissioning and restoration.

Internationally, offshore is one of the major areas of environmental liabilities. It is no longer acceptable to just tow a scrap rig to deeper waters and sink it. Instead, all structures above the bottom of the sea have to be taken ashore and either be recycled or be deposited in a landfill.

The decommissioning is organized somewhat differently as compared to other areas. Oil rigs represent enormous investments while the return in terms of oil production may be variable. Consequently, even large oil companies often own and operate oil rigs through consortia. In concordance, planning for decommissioning as well as issuing of financial assurances to Competent Authorities are also carried out through consortia based on consortia agreements.

Offshore decommissioning includes the challenges of deep water work with aged and possibly deteriorated large structures. However, most of the material retrieved is recycled, and residues are deposited mainly in ordinary landfills. Thus, offshore decommissioning does not have to deal with such sometimes large uncertainties that are associated with the decommissioning of nuclear facilities and their associated radioactivity nor does it have to take responsibility for long-term events in waste repositories such as may be the case for mining residues, contaminated soil, and nuclear waste.

Much of the above presented information on offshore decommissioning has been obtained by us through a membership with the Norwegian Petroleum Society (In Norwegian: Norsk Petroleumforening), see www.npf.no.

\subsection{Legislation}

\subsubsection{Nuclear technology legislation}

Nuclear safety is primarily regulated in Sweden by and under two laws: The Radiation Protection Act [31] and Act on Nuclear Activities [32]. Before July 1, 2008, they were overseen by the Swedish Radiation Protection Authority and the Swedish Nuclear Power Inspectorate, respectively, at which time these two Authorities merged to form Swedish Radiation Safety Authority.

As the name indicates, the Radiation Protection Act [31] is a general law covering essentially all radiation, that is, radiation that is emitted by radioactive substances as well as electromagnetically generated radiation. There exists a listing of low limits under which there is little radiological concern. The law states, among other things, that an apparatus that has the capability to radiate must be incapacitated when its useful life is over.

The Act on Nuclear Activities [32] is valid for facilities in which nuclear chain reactions take place and other related facilities. It is also valid for nuclear material (i.e. material that is fissile or can be activated to become fissile), for activated material (with several exceptions), and for nuclear waste. Permitting is required only for possession of material above certain de minimis levels, for example, $15 \mathrm{~g}$ of uranium- 235 or $5 \mathrm{~kg}$ of natural uranium. The law states, among other things, that the holder of a permit is obligated to manage any waste that is generated and to assume financial responsibility in accordance with the Nuclear Liability Act [33]. It should be noted that the de minimis levels above have nothing to do with the levels for free release of a facility. The obligations to manage the waste and to decommission appropriately persist until a consent has been received from the Competent Authority.

The Nuclear Liability Act [33] is valid for nuclear material that is not intended to be reused and for nuclear waste that is not a waste from daily operation. For nuclear power plants, there are two 'compartments' for securities and fees to segregated funds managed by the Government: 
(a) the anticipated costs for decommissioning and waste management etc., and

(b) a risk fee intended to cover the risk that the Government takes in its management of the fund system.

Compartment (a) comprises a combination of securities (unlimited in time) and assets in segregated funds. Securities are lifted at the same pace as that of the payments that flow into the segregated funds. In addition, securities must be provided to cover 'unplanned events'.

See Section 7 regarding the new ordinance and its implications for small facilities.

No legislation exists as to the details on how the decommissioning planning and the cost calculations are to be carried out in practice. Instead, the SSM has taken initiative to research where the results of past experience can be utilized by the facility owners as well as the Authorities [5-18]. Some of this research has been carried out in Nordic cooperation [11,12] and some has been part of IAEA activities [15]. Guidance documents to support planning and cost calculation activities have also been published by the IAEA [34-36], the US DOE [37], ASTM [38-40], International Accounting Standards Board (IASB) [41], the European Union [42], OECD/NEA [43], and others.

\subsubsection{The Swedish Environmental Code}

The Swedish Environmental Code [3] establishes a general and comprehensive basis for protection of health and the environment in Sweden. It also defines the polluter pays principle as quoted in Section 1.

The general statement cited above (see Section 1) from the Swedish Environmental Code may not be sufficient for full compliance and is therefore supplemented in the code and elsewhere with regard to specific areas. Thus, chapter $16 \S 3$ in our Environmental Code [3] states that permits issued under the code may be associated with requirements on securities corresponding to all future costs. The Government does not have to comply with this, however.

Another principle that is established in the code is the requirement of knowledge which is stated as follows: 'Persons who pursue an activity or take a measure, or intend to do so, must possess the knowledge that is necessary in view of the nature and scope of the activity or measure to protect human health and the environment against damage or detriment'.

\subsubsection{Financial reporting legislation}

The laws covering financial reporting for ordinary companies in Sweden are primarily the Accounting Act [44], Annual Reports Act [45] and the Swedish Companies Act [46]. The Accounting Act states in $\S 2$ that the obligation of book-keeping must be carried out in accordance with good practice.

'Good practice' has a somewhat different meaning depending on the size of the enterprise. Companies are divided into large companies with more than 50 employees and a certain minimum turnover and small companies (which are those that are not large). Large companies are obligated to follow the International Financial Reporting Standards and International Accounting Standards (IFRS/IAS) [41] issued by the International Accounting Standards Board, while small companies have to follow the general advice issued by Swedish Accounting Standards Board (in Swedish: Bokföringsnämnden, BFN) [47].

The idea is to simplify the rules for small enterprises and indeed the general advice is actually much shorter than the corresponding text found in the international standard. Both have strict requirements on how liabilities are to be specified. The international standard also provides relatively detailed instructions as to how the liability is to be evaluated. The general advice, however, 
provides little guidance. Moreover, the general advice states (point 1.6) that when in doubt, it is not permitted to make comparison with the international standard but to seek guidance in the 'fundamental principles of accounting' as expressed in the Annual Reports Act [45]. Thus, small enterprises can find little guidance in our financial reporting legislation as to how to evaluate environmental liabilities. Moreover, as elaborated below, the rules for research and development are widely different, and this may constitute an obstacle in conjunction with a segregated fund system (see further below).

\subsubsection{Criminal law and legal consequences}

Contrary to the financial reporting legislation, the Swedish Penal Code [48] is the same regardless of the size of the company. Actually, court decisions on punishment can be made based either on the specialized legislation or on the actual Swedish Penal Code. As a rule, the court selects the law that leads to the harshest punishment. On the other hand, the requirements on proof and intentions may be higher in the Swedish Penal Code.

For instance, the Nuclear Liability Act [33] states that anyone who deliberately or through considerable neglect submits incorrect cost calculations may have to pay fines.

The Swedish Penal Code [48], however, states that anyone who is obligated to follow the Accounting Act [44] but declares figures that are not correct so that the books no longer present an 'essentially correct financial situation' may be sentenced to jail for at most 6 years (in severe cases).

There is a clear possibility that errors and uncertainties in estimations of decommissioning costs may be large in comparison with the errors and uncertainties for other posts in financial books. It is therefore warranted to look somewhat into what kinds and levels of deviance that may be acceptable to an Auditor and to a court.

No large volume of domestic literature is available on this topic, but the present situation has been summarized in Reference [49]. First, it should be realized that courts decide on this matter on a case-by-case basis. Each case is different, and general patterns may not apply in individual cases.

There is a method of evaluation, called the Eloffson method, according to which an independent Auditor makes his or her evaluation. Acceptable deviance according to this method may be at most $30 \%$. There are other methods to discuss as well, but the interested reader is referred to the specialized literature.

\section{COMPLETED SWEDISH DECOMMISSIONING PROJECTS}

\subsection{Decommissioning of the first Swedish nuclear reactor, R1}

The first Swedish nuclear reactor, R1, was located in rock under the Royal Institute of Technology in Stockholm $[11,12,20]$. It was fuelled with metallic natural uranium and had heavy water together with a graphite reflector as moderators. It had a maximum thermal power of $1,000 \mathrm{~kW}$. The reactor was commissioned in 1954 and shut down in 1970 after having been used for $65,000 \mathrm{~h}$ for various research purposes.

A radiological survey for decommissioning was started in 1979. Work began on site in 1981 and went on until 1983 when Greenfield conditions had been attained.

The sampling of the graphite reflector was limited at the planning and cost estimating stage, since it gave rise to dose to personnel. It turned out once the reactor tank had been lifted that the dose rate was considerably higher than assessed. This meant an increase in cost as well as dose for this part of the project. 


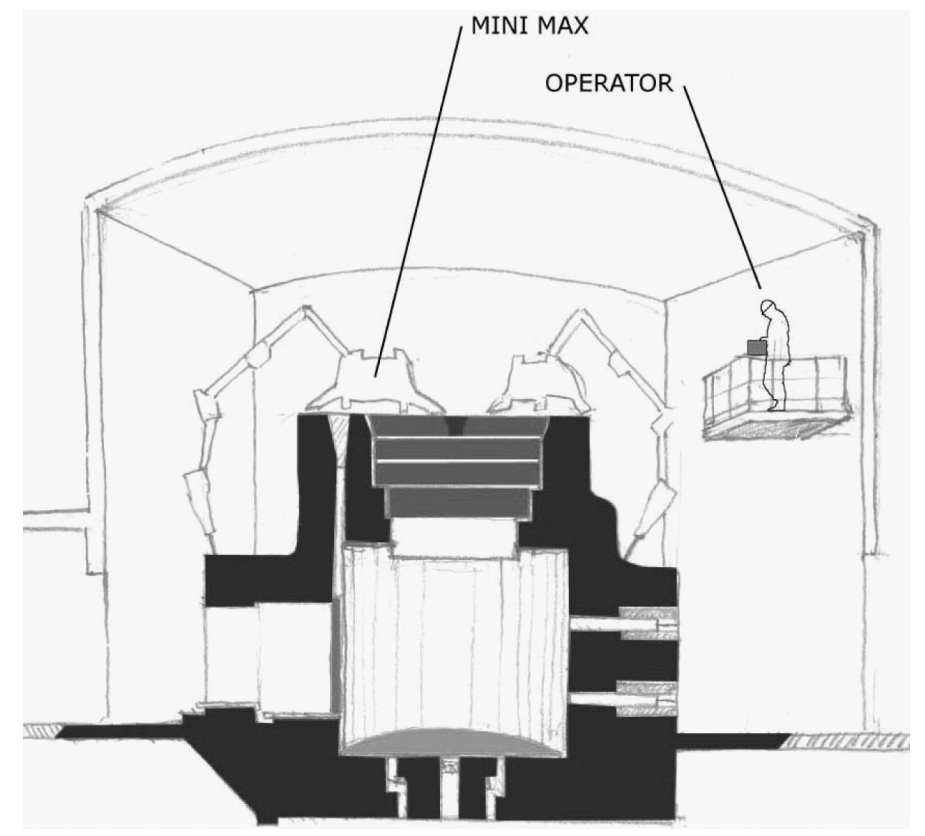

Figure 2: The R1 research reactor in Sweden undergoing decommissioning.

The facility had very little conventional equipment and structures, and therefore the decommissioning work had to be planned and executed using specially designed tools and other equipment as well as protective shields.

A timber handling machine was modified with a pneumatic hammer and remote controls. This made the work much more efficient and saved dose, and helped in reaching the time and cost targets for the project. (Actually, this was the origin of the present product line of the Swedish Brokk company.)

It can be noted that extensive information searches and plant visits were made in the planning stage and that the decommissioning was carried out while there was still ample access to people who had worked in the facility.

The time schedule was followed. Studsvik was granted a total of MSEK 25 for the demolition of $\mathrm{R} 1$, but the outcome was only MSEK 21.7. This corresponds to about M€10.6 and 9.2, respectively, at the price level of today. However, the dose budget for the project was 40 manmSv, while the outcome was 140 manmSv. A general description of the decommissioning project can be found in References $[11,12]$.

It might be added that the publications [11,12] came about on initiative by SSM. They are the first open publications on this project and appeared about 25 years after the work had been completed.

\subsection{Decommissioning of the Active Central Laboratory}

The Central Active Laboratory (ACL) at Studsvik, see Fig. 3, was part of the early Swedish domestic concept with natural uranium fuel, heavy water moderation, reprocessing, and mixed oxide fuel, see Section 3.1. The facility had had a very varied use, for example, laboratory scale reprocessing and preparation of mixed oxide fuel. 


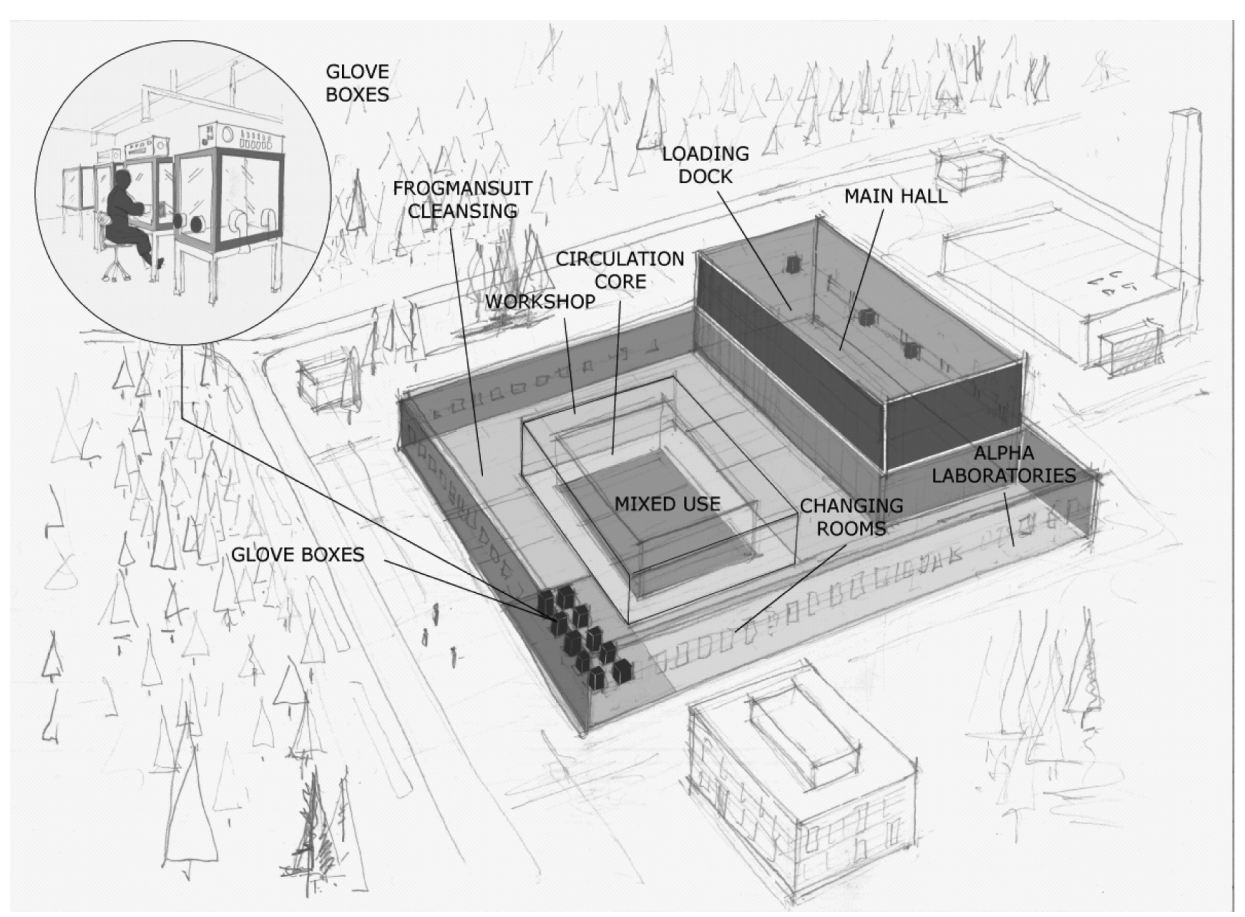

Figure 3: The Central Active Laboratory (ACL) at Studsvik, artist's view. ACL was used for laboratory scale reprocessing and preparation of mixed oxide fuel. The main hall was intended for a mixed oxide fuel pilot plant, but no such plant was ever built. The total floor area was $14,200 \mathrm{~m}^{2}$.

The laboratory was built from 1959 to 1963 and was decommissioned from 1998 to 2006. It had a total floor area of $14,200 \mathrm{~m}^{2}$.

Progress reports and experiences from the decommissioning have been presented in References [50-52]. There are substantial differences between the cost calculations at the different stages and most of them also deviate considerably from the final outcome. The reasons for this include the high alpha to gamma ratios and the varied use implying that the level of contamination varied substantially even between different rooms.

Reference [50] shares an important lesson learned: 'Early in 1999 decommissioning of area No 1 began. As the contamination levels had been underestimated and contamination was often found where it had not been expected, work had to be interrupted between July and September 2000 for planning and cost estimations. The work in area No 1 could be finished in September 2000'. (Work on areas 2 and 3 started in October 2000 and in September 2002, respectively.).

Decommissioning to Greenfield conditions was completed in the year 2006. No final report appears to have been published yet [53], but previous progress reporting [50-54] appears to indicate a total cost for the work conducted from the year 1988 of around MSEK 100, several times higher than the initial estimates. This corresponds to $M € 11$ at the present rate of exchange. Significant clean up was also conducted in the early 1980s but no figures for this appear to be mentioned in any modern source. 


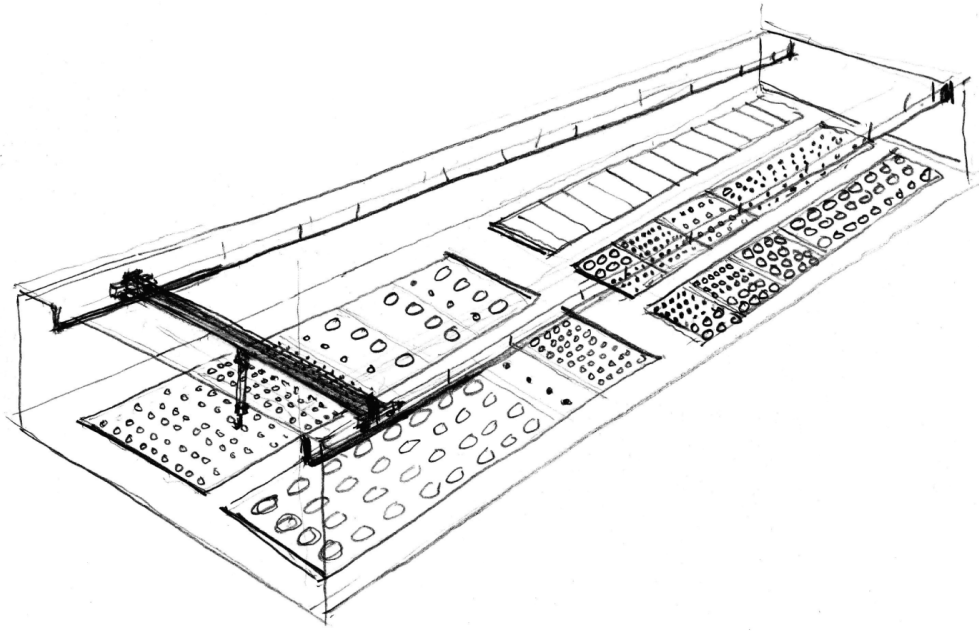

Figure 4: Layout of the storage for old intermediate level waste (SOILW) at Studsvik (artist's view). Compartments having large lids are open inside and most compartments with circular lids contain vertical pipes in concrete blocks which are about $3 \mathrm{~m}$ thick.

As a consequence of the demanding and diversified use, the facility had high and varying ratios of alpha emitters relative to gamma emitters. Alpha radiation has a short range and may readily be concealed under, for example, a coat of paint. Gamma radiation is usually comparatively easy to detect and measure with sufficient sensitivity. Therefore, one often attempts to determine the alpha to gamma ratio, and to use the gamma radiation as a tracer for the alpha radiation.

Thus, an important strategic decision was whether to decontaminate and measure or strip the concrete using, for example, Bolero equipment. According to Reference [51], the former method was used and the cost for radiological measurements and consultants constituted more than $50 \%$ of the total cost.

\section{STUDIES OF TWO FACILITIES AT STUDSVIK}

\subsection{Brief description of the facilities and the plans for decommissioning}

\subsubsection{Storage for old intermediate level waste}

The Storage for old intermediate level waste at Studsvik has been used for interim storage of intermediate- and high-level radioactive waste from various activities at the Studsvik site, including test reactor and hot cell laboratory operation. Some of the high-level waste comprised fuel debris and in some cases also slurry used for polishing of specimens. The material was packed in tins made of sheet metal.

The facility was in operation during the years 1961-1984. All waste was removed in 2001. The waste was stored in tube positions in concrete blocks and in concrete vaults. Further detail can be found in Reference [17] and references therein.

An overview of the facility is shown in Fig. 4. The facility comprises a number of storage compartments of two kinds, concrete blocks with vertical pipes for storage of tins as just described, see Fig. 5, and compartments with no internal structures for storage of intermediate-level 



Figure 5: Pipe position in the storage for old intermediate level waste at Studsvik (artist's view). Left: Stacking of the tins. Right: The planned removal of a pipe after an overcoring operation.

waste of various kinds. At the bottom, the vertical pipes enter into a ventilation area which is about 5-10 cm high, see Fig. 5. All storage compartments have thick concrete lids for radiation shielding. The facility has been emptied from radioactive waste but not cleaned. Significant levels of contamination are believed to exist on the surfaces of the vertical pipes and at the bottoms of the compartments.

The dose rates in the compartments with no internal structures are on the order of $0.5 \mathrm{mSv} / \mathrm{h}$, which is too high for work by man in situ (except possibly for very limited periods of time). The dose rate in the pipes used for stacking tins is believed to be high, at least at certain locations. The reason is that the tins contained not only fuel debris but also liquid, supposedly absorbed in vermiculite, containing nitric acid which caused corrosion of the tins as well as leakage and contamination of the pipe shafts. Also, it is known that small objects have dropped down to the ventilation area underneath and possibly caused contamination.

The plans for decommissioning include that the tube positions might be overcored to remove the contamination on the inside of the tubes, see Fig. 5. Once the main part of the radioactivity has been removed, it is planned that the remaining essentially inactive concrete will be fractured by means of drilling and mechanical fracturing into blocks that are sufficiently small to be removed using the existing crane.

\subsubsection{Interim store for spent nuclear fuel}

The interim store for spent nuclear fuel, see Fig. 6, was commissioned around 1964 and was still in operation in the year 2006 .

The store has been used for the interim storage of spent fuel from the Ågesta nuclear power plant and the $\mathrm{R} 2$ research reactor. The former had incidents of severe fuel damage [55] although it appears that at least some of the most damaged fuel was sent to Eurochemic for reprocessing and was therefore never received at the store [56]. Further details can be found in References [14,18] and references therein. 


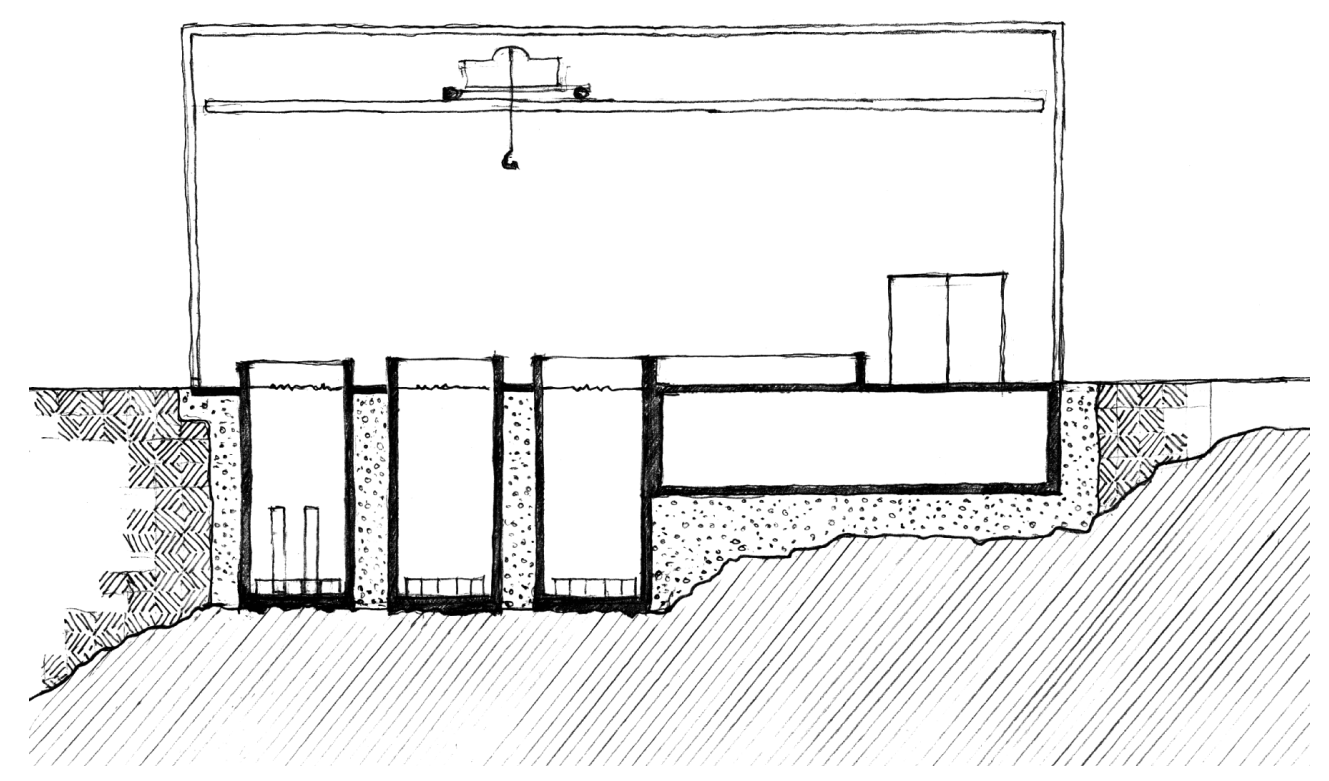

Figure 6: The spent fuel store at Studsvik showing the main hall as well as the interface between the building structures and the underlying soil and rock (artist's view).

The plant comprises a main hall with three cylindrical pools for spent fuel storage and a drained stainless steel surface for decontamination, see Fig. 6. The insides of the tanks are covered with glass fiber-impregnated epoxy which has become deteriorated in patches. The hall also contains an overhead crane and equipment for shielded handling of the fuel.

The contamination levels found are low for this type of facility, and it is expected that only part of the concrete surfaces need be removed by means of billing.

\subsection{Findings}

As a part of its research duties, the Swedish Nuclear Power Inspectorate, predecessor of the Swedish Radiation Safety Authority, has commissioned reviews of previous cost estimate reports, visits to facilities, and meetings with those responsible as well as information searches. The result of the work on the storage for old intermediate level waste has been published in Reference [17] (in 2004), and those for the interim store for spent nuclear fuel in Reference [18] (first published in 2005). Some of the findings were as follows.

1. IAEA and OECD/NEA documents provide invaluable advice for pertinent approaches.

2. Adequate radiological surveying is needed before precise cost calculations can be made.

3. The same can be said about technical planning including selection of techniques to be used.

4. It is proposed that separate analyses be made regarding the probabilities for conceivable features and events which could lead to significantly higher costs than expected.

5. It is expected that the need for precise cost estimates will dictate the pace of the radiological surveying and technical planning, at least in the early stages.

6. It is important that the validity structure for early cost estimates with regard to type of facility be fully appreciated. For example, the precision is usually less for research facilities. Also, costs 
for planning, research, and management constitute a larger fraction of the total cost for research facilities as compared to nuclear power plants.

7. The summation method is treacherous and leads to systematic underestimations in early stages unless compensation is made for the fact that not all items are included. See below.

8. Comparison between different facilities can be made when there is an access to the information from plants at different stages of planning and when accommodation can be made with regard to differences in features.

9. Information exchange and cooperations between different plant owners are highly desirable.

Furthermore, similar facilities were identified in which commissioning had already taken place. Thus, the literature survey conducted revealed [17] the existence of a similar but completed project [57], namely the East Map Tube Facility at Argonne National Laboratory in Illinois. Further information has been compiled, subsequently [58]. An important lesson learned at Argonne was the possibility of loss of contaminated drilling fluid through voids in the concrete.

In the case of the pool storage, it was found that the Studsvik facility has only a single barrier to the surrounding soil and rock. (Modern facilities have double containments and alarms for leakage in between.) Although contamination of surrounding soil and rock was assessed to be unlikely, it could not be ruled out. Costs for soil remediation can be higher than those for decommissioning of the facility giving rise to the contamination.

It was also analyzed how cost calculations could be carried out at early stages and still be as precise as possible. In particular, it was found desirable to avoid some of the systematic errors associated with the summation method (that works well in the late stages of planning).

It was found that comparisons could be made with parts of completed projects, using nonlinear scaling factors as is done in the chemical industry and as is described in textbooks.

The simplest way in which to achieve a scaling was found to be by simple linear factors, and as follows:

Let the cost for a plant be given by the equation

$$
K_{c}=\sum_{i} p_{i}
$$

where

$K_{c}=$ the total calculated cost, $p=$ cost item, and, $i=$ index for cost item.

A fit to actual cost $K_{a}$ for a completed project can be made using the weighing factors $w_{i}$ and a scaling factor $s$ according to the following equation:

$$
K_{a}-K_{c}=s \sum_{i} w_{i} p_{i}
$$

The weighing factors may be obtained by assessing which items should have a small, intermediate, large, or very large influence on the difference between calculated and actual values. For instance, a weighing factor can be given one of the values $1,2,4$, or 8 . The scaling factor can then be calculated using the equation:

$$
s=\left(K_{a}-K_{c}\right) / \sum_{i} w_{i} p_{i}
$$

For a plant for which a refined cost calculation is to be made, the cost items can be calculated first, and then the total cost according to the eqn (1) above. 
After that, an adjusted calculated total cost can be calculated using the equation:

$$
K^{\text {adjusted }}=\sum_{i}\left(1+s w_{i}\right) p_{i}
$$

This example is just one of many ways in which scaling and comparison might be achieved, but it shows that it is feasible and straightforward to make this kind of estimations.

\section{PLANNING FOR DECOMMISSIONING AND COST ESTIMATION}

The experience from the completed decommissioning projects (see Section 4) together with the results from the two studies (in Section 5) prompted collaborative work on old research facilities in the Nordic countries. The work came about on initiative by the Swedish Nuclear Power Inspectorate, now the Radiation Safety Authority, and was carried out with finance from and under the auspices of the Nordic Nuclear Safety Research (NKS). Details on this work can be found in References [11,12].

The results of the Nordic cooperative work are as follows:

1. The establishment of a Nordic network in the area of decommissioning of nuclear research facilities.

2. The compilation of a background for the prerequisites for precise cost calculations, including

- a brief general description of types of nuclear technology development work carried out historically in the Nordic countries and

- a brief survey of existing nuclear research types of facilities.

3. A guidance document for the prerequisites for precise cost calculations, including

- good practice on radiological surveying, including statistic prerequisites for sufficient data and interpretation,

- good practice on technical planning, including methodology selection including logistics and timing aspects,

- financial risk identification, assessment, and evaluation, including approaches similar in nature to hazard identification and safety analysis type of approaches.

4. Descriptions of techniques that may be applied at early stages of calculations and assessments of costs.

5. Presentations of examples of projects at different stages of planning and completion, including experiences made and lessons learned:

- the R1 research reactor in Sweden

- the reprocessing pilot plant in Norway

- the DR 1 research reactor in Denmark

- the TRIGA research reactor in Finland.

It was found that cost calculations for nuclear research facilities are particularly treacherous and uncertain for several reasons, including the following:

- Plans for decommissioning do not exist

- The facilities were not designed for decommissioning

- The facilities are small (which means that investigations can become expensive in relation to the total cost)

- The facilities are very different in character

- The types of contamination are different 
- The buildings were constructed and operated at a time when the regulations were considerably less strict than today

- Incomplete documentation of the operation history, accidents, and incidents causing contamination

- Institutional memory has been lost and people who are able to recall what took place may not be around any more

It was also found that in spite of these circumstances, and at least in favorable cases, a precision of $\pm 20 \%$ is attainable, even at an early stage.

\section{A NEW SWEDISH ORDINANCE AND SMALL NUCLEAR FACILITIES}

\subsection{Some nomenclature}

There are three levels of legislation in Sweden:

\begin{tabular}{llll}
\hline Legislation & Issued by & Compliance with & Authorized by \\
\hline Law & Parliament & Constitution & Swedish people \\
Ordinance & Government & Laws & Parliament \\
Regulation & Competent authority* & Laws and ordinances & Government \\
\hline
\end{tabular}

* Such as the Swedish Radiation Safety Authority.

Laws, ordinances, and regulations are legally binding and the compliance of them is overseen and assured by our legal system, including our courts. In addition, a Competent Authority can issue general advice with regard to a certain regulation. It can contain clarification as to what the actual regulation is intended to mean and may also provide examples. General advice is not legally binding and compliance must not necessarily be upheld in a court decision.

Competent Authorities - like everybody else, for example, a branch organization - can also issue guidance documents. They reflect good practice, but cannot necessarily be relied on for compliance with legislation.

\subsection{Background and challenge}

A new ordinance [59] was issued in November 2008, under the Nuclear Liability Act [33]. It states that those eligible under the law, who are not nuclear power reactor owners, are obligated to submit to SSM every third year a cost calculation comprising the following:

- The total best estimate for the cost for decommissioning and waste management;

- the expected remaining time of operation; and

- the proposed proportions between securities and assets in a segregated fund.

The novel feature of this ordinance is not that it introduces the polluter pays principle into Swedish legislation. Nor does it introduce legal requirements on appropriate book-keeping of environmental liabilities. Instead, the novel feature is that such requirements are now to be implemented and enforced in a rigorous manner in the entire area of nuclear technology, including small facilities. 
Thus, according to the new ordinance [59], all those who have permits under the Act of Nuclear Activities [32] are obligated to plan for decommissioning and to carry out cost calculations, which are to be reviewed by the SSM. Actually, this requirement may hold also for those whose permits have expired but who still have not had their decommissioning obligations lifted by the Competent Authority. Based on such a plan and such a cost calculation as well as on the outcome of the review, the SSM will then decide on what payments are to be made into a dedicated fund, what securities are to be provided and what obligations and liabilities might be managed solely by the holder of the permit.

The new ordinance has also granted the SSM the authority to issue regulation under the ordinance and to decide on exemption from requirements on securities as well as on payments to segregated funds.

It is essential that issuing of any regulation (or any other legislation) - as well as any Authority oversight - is carried out from a comprehensive perspective and in full awareness of the various needs and interests. Thus, our laws [2] and ordinances $[60,61]$ state a number of requirements that apply to any regulation:

- A regulation must contain a reasonable balance between different interests, and the benefits must be justified in comparison with the costs for compliance (Proportionality principle).

- All must be dealt with in an equal manner.

- There must not be any contradictions with any other legislation.

- There has to be a follow-up of the outcome, and adjustments made as appropriate from any lessons learned.

- A regulation must be simple and clear.

Consequently, the Swedish Radiation Safety Authority has found it appropriate to compile a knowledge base before any decisions are taken regarding any new regulation and on how to deal with the issue of exemption. The results of this research are presented in the subsequent section.

\subsection{The new ordinance}

The new ordinance covers a number of mutually very different cases. It is therefore imperative that the regulation be implemented in such a manner that the complexity of the analyses required as well as the ambition in the allocations of funds are well chosen in relation to the prerequisites for different facilities in question. Consequently, the analyses include the following:

- Identification of existing records including permits and applications, records of operation, and radiological surveys.

- Compilation of parameters of interest, for example, levels of radioactivity handled, alpha to gamma ratios, and whether or not the sources have been sealed.

- Type of facility, for example, prototype nuclear power reactor (Ågesta), fuel fabrication (enriched uranium), waste treatment facility (incineration, scrap metal melting), medical applications, research, and other industry.

- Owner category: limited stock company or government (national, regional, or local).

- Type of security: segregated funds, irrevocable financial instruments, bank guarantees, internal funds, or no reservation.

- Relation to existing financial systems, including segregated funds and producer responsibility arrangements. 
Moreover, as mentioned above, a regulation must not contradict any other legislation (cf. the compilation in Section 7.1), and that there must be proportionality between the obligations imposed on an enterprise and the intended effects.

These two requirements in combination imply that one must go through all other related legislation to find what is already required since earlier. This also includes such legislation that for various reasons might not yet be fully implemented. It is also essential in this regard to look for special cases where legislation might be contradictory or incompatible with what might fall under the new ordinance.

The first question with regard to how the new ordinance might best be implemented is perhaps exactly who ought to be considered and included. First, it should be reiterated that financing associated with the Radiation Protection Act [31], but not the Act on Nuclear Activities [32], is not included in the New Ordinance [59]. Instead, responsibility is here required under the rules for producer's responsibility as well as directly under the Radiation Protection Act (alternatively under the Environmental Code).

Thus, only those having or having had permits under the Act on Nuclear Activities [32] are included. It is plausible that it is the intent of the legislators also to include those who for 'historic' reasons have not had the opportunity to obtain permits under the Act on Nuclear Activities [32] but who should have had to do so under the legislation that exists today.

The next question is if some of those potentially eligible should or could be exempted after only very simple considerations. Cases of this nature might include those where it can be shown that all sources have been sealed, they have never leaked and they have all been removed. Other cases include those where all activity has been short-lived, and where radioactivity has decayed completely.

The main basis for assessing whether there an obligation to apply for and to hold a permit under the Act on Nuclear Activities exists rests on the limits of total activity for various types of radionuclides.

It would therefore be tempting to explore a similar path for determining when the dedicated funds, securities, and exemption should be selected. However, the co-variation between activity type and content in a facility and the costs and uncertainties for its decommissioning is very weak, as illustrated, for example, by the examples above. Consequently, this path was abandoned.

Instead, and as summarized above, it was found that the cost and associated uncertainty cannot be assessed in any useful manner unless proper decommissioning planning has been carried out, including radiological surveying, method selection, and uncertainty analysis. Such costs and uncertainties are therefore identified as the basis for when and how dedicated funds, securities, and exemption are to be used.

This implies that appropriate decommissioning planning and cost calculations will have to be required from all present and previous holders of permits under the law of Act on Nuclear Activities [32] (and its predecessors). This, in turn, raises the question whether such a requirement might be considered warranted in view of the requirement on proportionality between effects and efforts.

The review above of the requirements on financial reporting (cf. Section 3.3.3) shows, however, that stringent requirements on cost estimations already exist in that domain. No additional burden would thus be put on the facility owners and operators by the new ordinance [59]. Instead, synergy is achieved in that the basis for reporting can be the same.

The search for potential contradictions has, however, resulted in the identification of two potential problems. Large companies in Sweden must follow the IFRS/IAS [41]. Small companies are required to comply with good reporting practice by following the general advice [62] of the Swedish Accounting Standards Board (in Swedish: Bokföringsnämnden). In addition, small companies can find little or no guidance in the financial legislation as to how to actually evaluate environmental 
liabilities. One might be tempted to believe that they could then read and apply relevant parts of the IFRS/IAS standard. This is, however, forbidden by the Swedish Accounting Standards Board.

Moreover, the advice of the Swedish Accounting Standards Board states, contrary to the IFRS/ IAS, and in contradiction with the Annual Reports Act [45], that internal costs for research and development cannot be distributed over a period of time but must be accounted for as a cost for the specific year in question.

It is obvious that significant efforts have to be spent on planning as well as various investigations as a natural part of the total decommissioning undertaking for a facility. This is very different from the ordinary operation. For instance, the radiological characterization required for reasonable cost estimates to be obtained is usually far more extensive than what is needed for the ordinary operations.

It is therefore essential that companies managing their decommissioning under the new ordinance and under a system of segregated funds can allocate all outlays as expenses under the system of finance and have them balanced against the balance in the fund. It is also essential that this can be carried out swiftly even in the introductory stages when the fund balance may be low.

New plants or pieces of equipment are usually written off over cautiously chosen lifetimes. Similarly, the burden of decommissioning should be carried throughout those years during which the facility in question generates revenue.

In cases where such a system of finance has been inaugurated at the onset of operation, it can be expected that when the period of earning of revenue is over, the sum of fund balance and security equals the remaining costs, with additional security to match the uncertainty. In such a 'reference case', no additional payments or securities should be required after closing except for adjustments that may occur as a result of the recurrent cost estimations.

In cases where such a system of finance has not been inaugurated at the onset of operation, it might be viewed as warranted - based on the rules for accounting as well as on the polluter pays principle in the environmental code - that corrections be made such that a reference case situation is achieved instantly. However, such an approach may well be substantially more difficult for a company to handle in comparison with a situation when the transition can be carried out over the course of a number of years.

From a company point of view, it may also be difficult and impractical to suddenly allocate a lot of liquid assets into a Government fund. Transfer of securities might be much easier, in comparison. If such securities consist of plants and facilities, then it is a matter of mortgage. Albeit reducing the total value of a company, a mortgage still leaves liquid assets and other essentials for continued operation largely intact. The same can be said about securities in a bank.

Consequently, from a company point of view, it would be desirable

(a) to absorb the liability in portions over a number of years, and

(b) to provide securities initially and that such securities are gradually converted into assets in dedicated funds (see further below).

Alternative (a) above is in conflict with the rules for accounting of liabilities in annual reports (e.g. IFRS/IAS [41]). They state that it is the full liability that is to be reported.

The same rules might, however, also be interpreted to imply that it is the full liability for decommissioning that must be reported as soon as a facility has been taken into operation.

This would, however, be in conflict with the continuity principle, which says that an appraisal of a company should usually be based on the assumption that the business is continuous. (This value is usually much higher than the scrap value.) It might not be unreasonable to apply the continuity principle also to certain closed facilities, namely if the benefits of the facilities are still reaped in the 
present production at the nuclear power plants. This argument was used by the Swedish Government when the Studsvik fund was established.

A comparison with the situation for Swedish nuclear power plants shows that they have had to provide fund payments and securities to cover all future costs should the nuclear power plants be closed today. Comparison can also be made with the rules for assuming the costs of an investment. It is well known that investments are usually written off during a number of years.

The approach in the present paper is that all existing legislation is to be taken as prerequisites. The conclusion here is therefore that environmental liability is to be absorbed as soon as it can be identified and that the Nuclear Liability Act [33] and Swedish Penal Code [48] state that cost calculations have to be made and that they have to reflect the situation in a just manner.

The conclusion is also that it is feasible that this assumption of liability initially can take place in the form of submitting securities. For the long term, assets in dedicated funds is the pertinent option but it is desirable that they be filled over the course of a number of years.

The reason for the preference of assets in segregated funds is that securities in a company or in a bank are usually good only as long as the company is not insolvent. The longer the intended duration of the securities, the larger is the probability that a company becomes insolvent. Consequently, securities should preferably be used for short-term situations and for management of uncertainty.

For small facilities and for low estimated costs for decommissioning, securities might be preferred for simplicity reasons. For very low estimated costs, exemption might be appropriate.

The information search included looking for comparison criteria that could be used to select between the type and value of segregated funds, securities, and exemption.

It was found in the general advice issued by the Swedish Accounting Standards Board [41], point 16.6, that provisions for liabilities need not be declared if they are below kSEK 25 (about $\mathrm{k} € 2.8$ ). Similar lower limits exist in the tax domain. Thus, if SSM were not to accept to exempt liabilities below this level, then some complications could arise in relation to the rules for accounting.

No feature was found to support any selection of level of boundary between securities and segregated funds (cf. conclusions above on securities versus segregated funds). It should be considered, however, that there is a certain amount of administration associated with a fund, and this calls for a level that is not too low. At the same time, a segregated fund is a more robust alternative than securities. Perhaps MSEK 1.00 (about $\mathrm{k} € 111$ ) is a reasonable lower boundary for long-term liabilities. For short-term liabilities, securities should suffice, provided that the business in question is financially sound.

The IFRS/IAS [41] as well as the ASTM standards on decommissioning [37-39] presuppose and put forward that relatively exact figures can and must be provided even for decommissioning of complex facilities decades ahead in the future. In cases of uncertainty, the declaration should contain a risk analysis type of approach for cost estimation, including descriptions of scenarios together with assessments of their respective costs and relative probability.

It was found above, cf. Section 6, that for well-behaved cases and with proper evaluation, an uncertainty as low as $\pm 20 \%$ might be attained. In other cases, this might be difficult, for example, because it might not be possible to evaluate potential cost raisers unless the actual decommissioning work is carried out to a certain extent. In such cases, the uncertainty might approach or even exceed levels at which courts decide on sentences based on criminal law.

It is, of course, a criminal offence to mislead the concerned parties outside a company by making incorrect statements about the liabilities associated with future decommissioning. On the other hand, cases may appear where all the appropriate action has been taken to properly evaluate the cost but a high uncertainty still persists, and for good reasons. It should then be possible to document such findings in the annual report and still obtain discharge from liability for the management. 
Correspondingly, a high level of uncertainty should be accounted for in the system of finance implying higher than ordinary levels for the securities.

Surprises in retrospect are frequently difficult to handle in this regard. If - or when - they occur, it is very helpful if the planning for decommissioning and the cost estimations have been carried out in accordance with all legislation and best practices in the industry and that all the work and findings have been properly documented.

\section{DISCUSSION AND CONCLUSIONS}

Application of the polluter pays principle simultaneously with the principle of equity between generations - albeit simple in principle - may require extensive awareness and substantial efforts for compliance to be achieved. One of the most treacherous types of cases appears when there is a substantial difference in time between the operation of a facility and its decommissioning. The requirement that adequate funds must be available at the time when they are needed implies that the timing of technical planning must be carried out according to the needs of financing and not necessarily that of technology.

A number of needs compete for the resources, and it is essential that adequate attention is given to the long-term responsibilities. They comprise a multitude of issues.

Experience from previous cost estimations - in Sweden as well as internationally - is that this is a treacherous area with a number of possible pitfalls. It is essential that existing guidelines and lessons learnt are utilized so that the state-of-the-art results can be generated. This includes that experience should be shared between different facilities and such material utilized to improve the realism in early stage cost estimations. It is also essential that special analyses are carried out with regard to potential cost raisers. They have indeed caused much of the deviations between prognoses and outcomes in the past.

Uncertainties may prevail, however, even if international handbook material and standards are utilized. In such cases, it is essential that the uncertainties are declared and the reasons clearly documented. This will not only lead to realistic and robust securing of funds but also maintain the good reputation of the organizations and persons involved.

As mentioned above, it is the responsibility of the operator/owner to possess and when necessary acquire the knowledge needed to achieve these aims. A prerequisite for this is that information on decommissioning projects are documented and distributed. If the financing is public, that is, by segregated funds managed by the Government, then it is expected that the publications are openly available. If areas of proprietary interest can be identified, for example, in cases where a company has invested considerable resources of its own in some specific technique, then it must also be possible to identify such areas and find consensus to leaving them out of open reporting.

It was pointed out in the examples given that radiological data from operation are, in general, not adequate for the planning for decommissioning. It should also be observed that the legislations are also different between operation, decommissioning, and finance. Thus, termination of license may come about as a result of decisions under the Radiation Protection Act [31] and the Act on Nuclear Activities [32]. Any such decision has no direct relevance for end of liability, which can only be achieved as a result of an Authority, Court, or Government decision under the Nuclear Liability Act [33]. It is reasonable to expect that no such decision will be made unless there is some type of report explaining how the decommissioning project in question was carried out, and how the money in the fund was spent.

Generally, the possibility to perform industrial activities that have a potential to harm health and the environment presupposes that public acceptance and Authority consent can be deserved and 
achieved. This includes also liabilities that extend far into the future. It is essential in this regard that there is a good communication with the Authorities as well as with the public.

Research suggests that an individual will sacrifice consumption to benefit future generations only if the guarantee exists that others will also do so [63]. Thus, modern bodies are needed as ombudsman for the public and various interested parties. Such solutions are proposed in Reference [63]. It is important in this regard to realize that we do have access to the values of one future generation, see Reference [6].

This paper has for the very most part dealt with nuclear technology. There are good reasons to believe that the issues and needs are similar in other areas as well, for example, for forestry, contaminated land, and contaminated offshore. The information searches carried out within the present work indicate that there is surprisingly little contact between these areas although many of the problems and solutions may be similar.

\section{ACKNOWLEDGMENTS}

The authors would like to thank the editor and the anonymous referees for their helpful suggestions and insightful comments that have improved the content and presentation of this paper. They also like to thank Professor Carlos Brebbia for the valuable discussions on the content and presentation of the paper, and Mrs Elizabeth Cherry, also at WIT, for her enthusiastic support. The illustrations were prepared by Fabian Sjöblom. Financial support has been received from the Swedish Radiation Safety Authority and from the Nordic Nuclear Safety Research.

\section{REFERENCES}

[1] Brundtland, G., Chairman, Our Common Future (The Brundtland report). World Commission on environment and Development, Oxford University Press, Oxford, United Kingdom, 1987.

[2] Constitution of Sweden, (In Swedish; Kungörelse (1974:152) om beslutad ny regeringsform). SFS 1974:152.

[3] The Swedish Environmental Code. English translation. Ds 2000:61. (In Swedish Miljöbalk, SFS 1998:808).

[4] Munche, J-F., The architect in the nuclear age. Design of buildings to house radioactivity. Iliffe Books Ltd., London, 1964.

[5] Lindskog, S. \& Sjöblom, R., Implementation of the polluter pays principle - example of planning for decommissioning. Environmental Economics and Investment Assessment III. WIT Transactions on Ecology and the Environment, 131, pp 27-38, 2010. doi: http://dx.doi. org/10.2495/EEIA100031

[6] Labor, B. \& Lindskog, S., Values held by young stakeholders on financial planning regarding liabilities for nuclear decommissioning. Environmental Economics and Investment Assessment III. WIT Transactions on Ecology and the Environment, 131, pp 235-246, 2010. doi: http://dx.doi.org/10.2495/EEIA100201

[7] Tyszkiewicz, B. \& Labor, B., A Survey of Younger Citizens Values towards Decommissioning and Dismantling of Older Nuclear Facilities in a European Perspective. SKI* Report 2008:52. June, 2008.

[8] Lindskog, S. \& Sjöblom, R., Radiological, technical and financial planning for decommissioning of small nuclear facilities in Sweden. Proceedings of the 12th International Conference on Environmental Remediation and Radioactive Waste Management, ICEM2009, October 11-15, Liverpool, UK, 2009.

[9] Lindskog, S., Cato, A. \& Sjöblom, R., Estimations of costs for dismantling, decommissioning and associated waste management of nuclear facilities, and associated impact on decision 
processes, functioning of markets and the distribution of responsibilities between generations. Environmental Economics II. WIT Transactions on Ecology and the Environment, Vol 108, pp 97-105, 2008. doi: http://dx.doi.org/10.2495/EEIA080101

[10] Lindskog, S. \& Sjöblom, R., Regulation evolution in Sweden with emphasis on financial aspects of decommissioning. Decommissioning Challenges: an Industrial Reality? Sept. 28 to Oct. 2 - Avignon, France, 2008.

[11] Iversen, K., Salmenhaara, S., Backe, S., Cato, A., Lindskog, S., Callander, C., Efraimsson, H., Andersson, I. \& R. Sjöblom, R., Cost calculations at early stages of nuclear facilities in the Nordic Countries. The 11th International Conference on Environmental Remediation and Radioactive Waste Management. September 2-6, 2007, Bruges (Brugge), Belgium.

[12] Andersson, I., Backe, S., Iversen, K., Lindskog, S., Salmenhaara, S. \& Sjöblom, R., Cost calculations for decommissioning and dismantling of nuclear facilities. Nordic Nuclear Safety Research, Project NKS-R, Report number NKS-165, July, 2008.

[13] Cato, A., Lindskog, S. \& Sjöblom, R., Financial Planning as a Tool for Efficient and Timely Decommissioning of Nuclear Research Facilities. American Nuclear Society. Decommissioning, Decontamination and Reutilization. Capturing Decommissioning Lessons Learned. September 16-19, Chattanooga, Tennessee, USA, 2007.

[14] Sjöblom, R., Sjöö, C., Lindskog, S. \& Cato, A., Early stage cost calculations for determination and decommissioning of nuclear research facilities. The 10th International Conference on Environmental Remediation and Radioactive Waste Management. Glasgow, UK, 4-8 September, 2005.

[15] Laraia, M. \& McIntyre, P. J., responsible officers; Cato, A., Lindskog, S. \& Sjöblom. R. et al contributors. Decommissioning of research reactors and other small facilities by making optimal use of available resources. IAEA Report Series 463, Vienna, 2008.

[16] Lindskog, S., Sjöblom, R. \& Labor B., Sustainability of nuclear energy with regard to decommissioning and waste management. Energy and Sustainability III. WIT Transactions on Ecology and the Environment, 143, pp 303-314, 2011. doi: http://dx.doi.org/10.2495/ESUS110261

[17] Sjöblom, R. \& Lindskog, S., An applied study of the storage for old intermediate level waste at the Studsvik site. SKI Report 2004:11. The Swedish Nuclear Power Inspectorate, February 2004.

[18] Sjöblom, R., Sjöö, C., Lindskog, S. \& Cato, A., Cost studies on decontamination and dismantling of nuclear facilities; the interim storage for spent nuclear fuel. (In Swedish: Kärntekniska kostnadsstudier avseende dekontaminering och nedläggning; Mellanförvaret för använt kärnbränsle i Studsvik). SKI Report 2006:20. The Swedish Nuclear Power Inspectorate, April, 2006.

[19] Controlled nuclear chain reaction, the first 50 years. American Nuclear Society, 1992.

[20] Studsvik, Swedish research establishment. EuroNuclear, September, 1965.

[21] Österlundh, C.G. \& Erwall, L.G., Erzeugung und Anwendung von Radioisotopen. (In German; Production and use of radioisotopes) Die Atomwirtschaft, February, 1963.

[22] Aler, B., Survey of Sweden. Nuclear Engineering International, September, 1970.

[23] Bladh, R., and Eriksson, O., 40 år I Studsvik. (In Swedish; 40 years at Studsvik). Studsvik AB.

[24] Larsson, K.-E., The nuclear reactor RI - some high technology pioneer history. (Kärnreaktorn R1 - ett stycke högteknologisk pionjärhistoria, in Swedish). Daedalus. Tekniska museets årsbok, årgång 50, 1981.

[25] Mc Hugh, B., Editor, The Ågesta Nuclear Power Station - a staff report. AB Atomenergi, Stockholm, 1964.

[26] Fjæstad, M., \& Jonter, T., The Rise of the Nuclear System of Innovation in Sweden. Svenska ekonomisk-historiska mötet i Stockholm, 2007. 
[27] The older Westgothia law. (In Swedish: Äldre Västgötalagen, översatt och förklarad av Nat. Beckman). Appelbergs Boktryckeri Aktiebolag, Uppsala, 1924.

[28] The Swedish Forestry Act. (In Swedish Skogsvårdslagen). SFS:429, 1979.

[29] Lindeström, L., The environmental history of the Falun Mine. Almqvist \& Wiksell Tryckeri, Uppsala, 2003.

[30] Lindroth, S., Mining and copper beneficiation at the Great Copper Mountain. (In Swedish: Gruvbrytning och kopparhantering vid Stora Kopparberget). Almqvist \& Wiksell Boktryckeri AB, Uppsala, 1955.

[31] Radiation Protection Act. (In Swedish: Strålskyddslag). SFS 1988:220.

[32] Act on Nuclear Activities. (In Swedish: Lag om kärnteknisk verksamhet). SFS 1984:3.

[33] Nuclear Liability Act. (In Swedish: Lag om finansiella åtgärder för hanteringen av restprodukter från kärnteknisk verksamhet). SFS 2006:647.

[34] Decommissioning of nuclear power plants and research reactors. Safety Guide. IAEA safety standard series No WS-G.2.1.6.

[35] Decommissioning of Nuclear fuel cycle facilities. Safety Guide. IAEA safety standard series No WS-G.2.4.7.

[36] Decommissioning of medical, industrial and research facilities. Safety Guide. IAEA safety standard series No WS-G.2.2.8.

[37] Decommissioning Handbook. Procedures and practices for decommissioning. Office of Environmental Management. U.S. Department of Energy, Washington, D.C. 20585, USA. DOE/EM-0383, January 2000.

[38] Standard Guide for Nuclear Facility Decommissioning Plans. ASTM standard E1281 89(2005).

[39] Standard Guide for Estimating Monetary Costs and Liabilities for Environmental Matters. ASTM Standard E 2137 - 06, December, 2006.

[40] Standard Guide for Disclosure of Environmental Liabilities. ASTM Standard E 2173 - 07, April 2007.

[41] International Financial Reporting Standards and International Accounting Standards (IFRS/ IAS). International Accounting Standards Board. 2008.

[42] European Union Recommendation "on the management of financial resources for the decommissioning of nuclear installations, spent fuel and radioactive waste". Brussels, 24 October $\mathrm{C}(2006) 3672$.

[43] Decommissioning Nuclear Power Plants: Policies, Strategies and Costs. Nuclear Energy Agency, Organization for Economic Co-operation and development, OECD/ NEA, 2003.

[44] Accounting Act. (In Swedish: Bokföringslag). SFS 1999:1078

[45] Annual Reports Act. (In Swedish: Årsredovisningslag). SFS 1995:1554

[46] The Swedish Companies Act. (In Swedish: Aktiebolagslagen). SFS 2005:551.

[47] Bokföringsnämndens allmänna råd om årsredovisning $i$ mindre aktiebolag. (General advice on annual reporting in small companies issued by the Swedish Accounting Standards Board, In Swedish).

[48] The Swedish Penal Code. (In Swedish: Brottsbalk). SFS 1962:700.

[49] Dahlqvist, A.-L. \& Elofsson, S., Crimes in accountance and the law. (Swedish title: "Bokföringsbrott och bokföringslagen"). Norstedts juridik, Stockholm, 2005.

[50] Jonsson, B., Bergstrom, L. \& Lindberg, M., Decommissioning of the ACL and ACF plants in Studsvik, Sweden. Waste Management '04 Conference, February 29 - March 4, Tucson, Arizona, USA, 2004. 
[51] Hedvall, H.R., Stridsman, K.H., Berg, R.S. \& Johnsson, B., Project evaluation of the decommissioning of a laboratory plant at Studsvik. Waste Management '06 Conference, February 26 - March 2, Tucson, Arizona, USA, 2006.

[52] Ellmark, C., Eriksson, A. \& Lindberg, M., Lessons learned from decommissioning of a research laboratory and how to apply these on upcoming decommissioning projects at the Studsvik site. ICEM'07. The 11th international conference on environmental remediation and radioactive waste management, Brugge, Belgium, September 2-6, 2007.

[53] Hedvall, R., Lessons learned from the decommissioning of contaminated small waste storage facilities and other papers presented at the Seminar on Decommissioning of nuclear facilities. Studsvik 2010-09-14 - 16. Arranged by The Nordic Nuclear Safety Research, The Swedish Nuclear Fuel and Waste Management Company, and Studsvik.

[54] The NEA Co-operative programme on decommissioning. A decade of progress. Radioactive waste management, OECD/ NEA, 2006.

[55] Sandstedt, K.E. \& Mogard, H., Operating experience with the Ågesta nuclear power plant. Proceedings of the fourth international conference on peaceful uses of atomic energy. Jointly sponsored by the United Nations and the International Atomic Energy Agency and held in Geneva 6 - 16 September, 1971.

[56] Österlundh, C.G., Former member of staff at Studsvik. Private communication.

[57] Moos, L. P., Wescott, J. B., Flemming, D. L., Subbaraman, G. \& Horton, P., Decontamination and dismantlement of the Argonne National Laboratory - East Map Tube Facility. One of the papers in 15],volume 1, pp 164-167.

[58] Varley, G. \& Ruch, C., An applied study on the decontamination and decommissioning of the map tube facility, 317 area, Argonne National Laboratory, Chicago. SKI Report 2005:34. Swedish Nuclear Power Inspectorate, January, 2005.

[59] Ordinance on financial action for the management of residues from nuclear technology activities. (Förordning om finansiella åtgärder för hanteringen av restprodukter från kärnteknisk verksamhet, in Swedish). SFS 2008:715.

[60] Ordinance on Regulatory Impact Assessment. (In Swedish: Förordning om konsekvensutredning vid regelgivning. SFS 2007:1244

[61] Ordinance on obtaining an Opinion from the Swedish Better Regulation Council. (In Swedish: Förordning om myndigheters inhämtande av yttrande från Regelrådet.) SFS 2008:530

[62] Bokföringsnämndens allmänna råd om årsredovisning $i$ mindre aktiebolag. (General advice on annual reporting in small companies issued by the Swedish Accounting Standards Board, In Swedish).

[63] Padilla, E., Intergenerational equity and sustainability. Ecological Economics 41, pp. 69-83, 2002. doi: http://dx.doi.org/10.1016/S0921-8009(02)00026-5 